WOODHEAD PUBLISHING SERIES IN CIVIL AND STRUCTURAL ENGINEERING

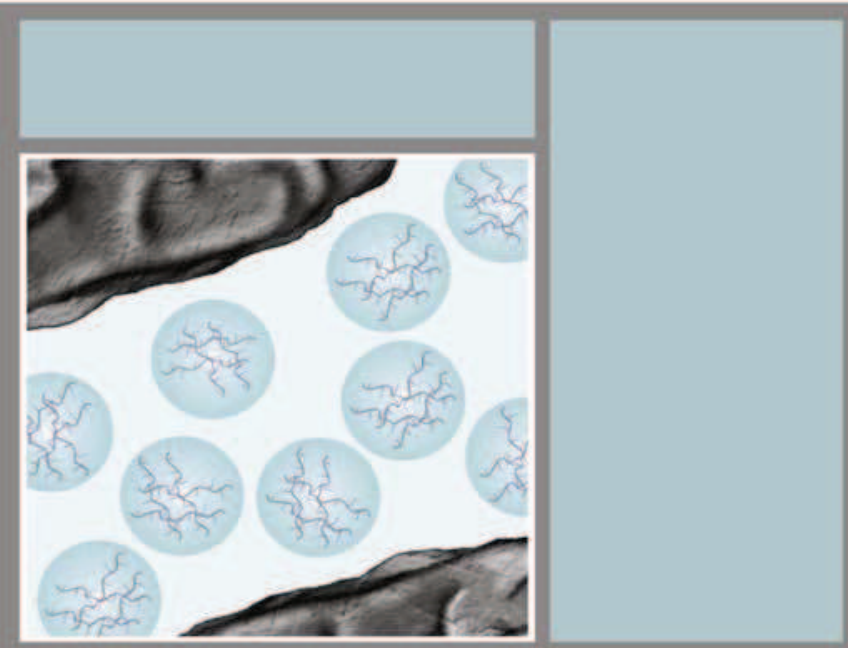

Biopolymers and

Biotech Admixtures

for Eco-Efficient

Construction Materials

Edited by Fernando Pacheco-Torgal, Volodymyr Ivanov, Niranjan Karak and Henk Jonkers 
Biopolymers and Biotech Admixtures for Eco-Efficient Construction Materials 


\section{Related titles}

Eco-efficient masonry bricks and blocks: Design, properties and durability (ISBN 978-1-78242-305-8)

Handbook of alkali-activated cements, mortars and concretes

(ISBN 978-1-78242-276-1)

Understanding the tensile properties of concrete

(ISBN 978-0-85709-045-4) 
Woodhead Publishing Series in Civil and Structural Engineering: Number 63

\section{Biopolymers and Biotech Admixtures for Eco-Efficient Construction Materials}

Edited by

Fernando Pacheco-Torgal, Volodymyr Ivanov, Niranjan Karak and Henk Jonkers

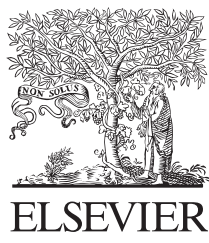

AMSTERDAM • BOSTON • CAMBRIDGE • HEIDELBERG LONDON • NEW YORK • OXFORD • PARIS • SAN DIEGO SAN FRANCISCO • SINGAPORE • SYDNEY • TOKYO

Woodhead Publishing is an imprint of Elsevier

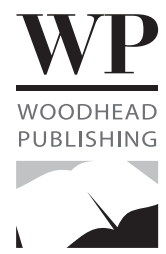


Woodhead Publishing is an imprint of Elsevier

The Officers' Mess Business Centre, Royston Road, Duxford, CB22 4QH, UK

225 Wyman Street, Waltham, MA 02451, USA

Langford Lane, Kidlington, OX5 1GB, UK

Copyright (C) 2016 Elsevier Ltd. All rights reserved.

No part of this publication may be reproduced or transmitted in any form or by any means, electronic or mechanical, including photocopying, recording, or any information storage and retrieval system, without permission in writing from the publisher. Details on how to seek permission, further information about the Publisher's permissions policies and our arrangements with organizations such as the Copyright Clearance Center and the Copyright Licensing Agency, can be found at our website: www.elsevier.com/permissions.

This book and the individual contributions contained in it are protected under copyright by the Publisher (other than as may be noted herein).

\section{Notices}

Knowledge and best practice in this field are constantly changing. As new research and experience broaden our understanding, changes in research methods, professional practices, or medical treatment may become necessary.

Practitioners and researchers must always rely on their own experience and knowledge in evaluating and using any information, methods, compounds, or experiments described herein. In using such information or methods they should be mindful of their own safety and the safety of others, including parties for whom they have a professional responsibility.

To the fullest extent of the law, neither the Publisher nor the authors, contributors, or editors, assume any liability for any injury and/or damage to persons or property as a matter of products liability, negligence or otherwise, or from any use or operation of any methods, products, instructions, or ideas contained in the material herein.

ISBN: 978-0-08-100214-8 (print)

ISBN: 978-0-08-100209-4 (online)

British Library Cataloguing-in-Publication Data

A catalogue record for this book is available from the British Library

Library of Congress Cataloging-in-Publication Data

A catalog record for this book is available from the Library of Congress

For information on all Woodhead Publishing publications

visit our website at http://store.elsevier.com/

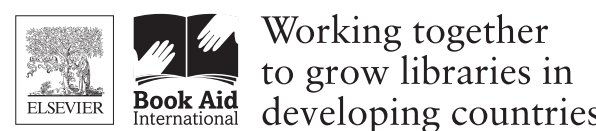

www.elsevier.com • www.bookaid.org 


\section{Contents}

List of contributors $\quad$ xi

Woodhead Publishing Series in Civil and Structural Engineering xv

Foreword $\quad$ xix

1 Introduction to biopolymers and biotech admixtures for eco-efficient construction materials

F. Pacheco-Torgal

1.1 Introduction

1.2 Biopolymers and biotech admixtures for eco-efficient construction materials

1.3 Outline of the book

References

\section{Section One Production of biopolymers for eco-efficient construction materials}

2 Basic concepts on biopolymers and biotechnological admixtures for eco-efficient construction materials

V. Ivanov, V. Stabnikov

2.1 Construction biotechnology 13

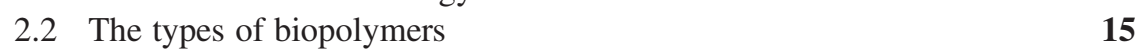

2.3 Microbial polysaccharides and their applications in civil engineering $\quad \mathbf{1 7}$

2.4 Bioclogging of soil using in situ production of microbial polysaccharides

2.5 Microbial plastics for civil engineering $\quad \mathbf{2 1}$

2.6 Biocements and biogrouts $\quad \mathbf{2 2}$

2.7 Conclusions $\quad 28$

References $\quad 29$

3 Biotechnological production of biopolymers and admixtures for eco-efficient construction materials

V. Stabnikov, V. Ivanov

3.1 Biotechnology for the production of construction materials

3.2 Biotechnological production of bioplastics for construction

3.3 Biotechnological production of polysaccharide admixtures

3.4 Biotechnological production of biocements and biogrouts 
3.5 Conclusions

References $\quad \mathbf{5 2}$

$4 \quad$ Life cycle assessment of biopolymers $\quad 57$

$\begin{array}{ll}\text { A.D. La Rosa } & \text { Introduction } \\ 4.1 \quad & \mathbf{5 7}\end{array}$

4.2 Biopolymers $\quad \mathbf{5 8}$

4.3 Life cycle assessment (LCA) method and models

$\begin{array}{ll}4.4 & \text { LCA of biopolymers } \\ 4.5 & 67\end{array}$

4.5 Future research trends and conclusion $\quad \mathbf{7 4}$

$\begin{array}{ll}\text { References } & \mathbf{7 5}\end{array}$

Section Two Biopolymers and biotech admixtures in cement and mortars $\quad 79$

5 Biotech admixtures for enhancing portland cement hydration $\quad 81$

A. Vazquez, T.M. Pique
5.1 Introduction

$\begin{array}{ll}5.2 & \text { Portland cement hydration } \\ 5.3 & \mathbf{8 2}\end{array}$

$\begin{array}{ll}5.3 \text { Biotech admixtures } & \mathbf{8 3}\end{array}$

$\begin{array}{lll}5.4 & \text { Summary and future trends } & \mathbf{9 6}\end{array}$

References $\quad 96$

6 Black liquor waste as a cement admixture or cement and concrete admixtures

H.H.M. Darweesh

6.1 Introduction 99

6.2 Air-entraining admixtures 99

$\begin{array}{lll}6.3 & \text { Plasticizers } & \mathbf{1 0 2}\end{array}$

$\begin{array}{lll}6.4 & \text { Superplasticizers } & \mathbf{1 0 5}\end{array}$

$\begin{array}{lll}6.5 & \text { Retarders } & \mathbf{1 0 8}\end{array}$

$\begin{array}{lll}6.6 & \text { Accelerators } & 109\end{array}$

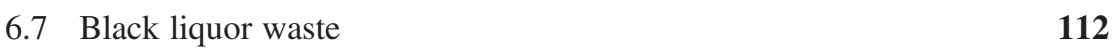

$\begin{array}{lll}6.8 \text { Water-resisting admixtures } & \mathbf{1 2 1}\end{array}$

6.9 Conclusion $\quad \mathbf{1 2 6}$

6.10 Future trends $\quad 126$

Cement notation $\quad 127$

Acknowledgements $\quad 127$

$\begin{array}{ll}\text { References } & 127\end{array}$

7 High-performance superplasticizer based on chitosan 131

$\begin{array}{ll}\text { S.H. } & \mathrm{Lv} \\ 7.1 \quad \text { Introduction } & \mathbf{1 3 1}\end{array}$

$\begin{array}{lll}7.1 & \text { Introduction } & \mathbf{1 3 1} \\ \mathbf{7 . 2} & \text { Structure and properties of chitosan } & \mathbf{1 3 3}\end{array}$

$\begin{array}{lll}7.3 & \text { High-performance superplasticizer based on chitosan } & \mathbf{1 3 4}\end{array}$ 
7.4 Dispersion capacity characterization of the chitosan superplasticizer $\quad \mathbf{1 3 7}$

7.5 Adsorption properties of SCS on the cement surface $\mathbf{1 4 0}$

7.6 The application results of SCS in concrete $14 \mathbf{1 4 2}$

7.7 Microstructure characterization of hardened cement paste $\quad \mathbf{1 4 4}$

$\begin{array}{lll}7.8 \text { Working mechanism of SCS } & \mathbf{1 4 5}\end{array}$

$\begin{array}{ll}\text { 7.9 Conclusion and future research trends } & \mathbf{1 4 7}\end{array}$ $\begin{array}{ll}\text { References } & 148\end{array}$

8 Microorganism-based bioplasticizer for cementitious materials $\quad 151$

F. Martirena, Y. Rodriguez-Rodriguez, A. Callico, Y. Diaz,

G. Bracho, A. Hereira, J.O. Guerra de Leon, L. Sorelli, Y. Alvarado-Capó

$\begin{array}{ll}8.1 \text { Introduction } & \mathbf{1 5 1}\end{array}$

8.2 Efficient microorganisms and their use in construction $\mathbf{1 5 2}$

$\begin{array}{ll}\text { 8.3 EM characterization } & \mathbf{1 5 2}\end{array}$

$\begin{array}{lll}\text { 8.4 EM as plasticizer in cement } & \mathbf{1 5 5}\end{array}$

$\begin{array}{ll}\text { 8.5 EM as plasticizer in concrete } & \mathbf{1 6 0}\end{array}$

8.6 Assessment of the impact of EM on the microstructure of concrete $\mathbf{1 6 3}$

$\begin{array}{ll}\text { 8.7 EM as viscosity modifier in concrete } & \mathbf{1 6 6}\end{array}$

$\begin{array}{ll}8.8 \text { Conclusions } & 169\end{array}$

References $\quad 169$

9 Fly ash-based geopolymer with kappa-carrageenan biopolymer 173

Z. Li, L. Zhang

$\begin{array}{lll}9.1 & \text { Introduction } & \mathbf{1 7 3}\end{array}$

$\begin{array}{lll}9.2 & \text { Experimental study } & 177\end{array}$

$\begin{array}{llr}9.3 \text { Results } & \mathbf{1 7 9}\end{array}$

$\begin{array}{ll}9.4 \text { Discussion } & \mathbf{1 8 5}\end{array}$

$\begin{array}{ll}\text { 9.5 Conclusions and suggestions for future work } & \mathbf{1 8 7}\end{array}$

$\begin{array}{ll}\text { References } & 187\end{array}$

Section Three Biopolymers and biotech admixtures in concrete 193

10 Biopolymers with superplasticizer properties for concrete 195

U.T. Bezerra

$\begin{array}{lll}10.1 & \text { Introduction } & \mathbf{1 9 5}\end{array}$

10.2 Biopolymers with superplasticizer properties $\quad \mathbf{2 0 3}$

10.3 Use of biopolymers in concrete: case studies $\mathbf{2 1 6}$

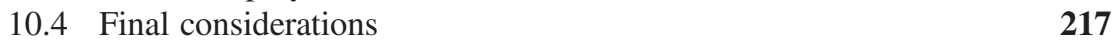

$\begin{array}{ll}\text { References } & 218\end{array}$

11 Biopolymers with viscosity-enhancing properties for concrete 221

P.F. de J. Cano-Barrita, F.M. León-Martínez

$\begin{array}{lll}11.1 & \text { Introduction } & \mathbf{2 2 1}\end{array}$

11.2 Basic concepts of rheology and viscosity-enhancing admixtures $\mathbf{2 2 2}$ 
11.3 Biopolymers in current used as viscosity-enhancing admixtures

11.4 Biopolymers with potential for future use as viscosity-enhancing admixtures

11.5 Future trends References

12 Biotech solutions for concrete repair with enhanced durability

H.M. Jonkers, R.M. Mors, M.G. Sierra-Beltran, V. Wiktor

12.1 Introduction

12.2 Biotechnological strategies for durable repair of concrete structures

12.3 Bacterial production of limestone in alkaline environments

12.4 Liquid bacteria-based system for durable repair of porous concrete structures

12.5 Biobased mortar systems for structural repair of concrete defects

12.6 Conclusions and future trends $\quad \mathbf{2 6 7}$

Acknowledgments

268

References

\section{Section Four Other biopolymer applications}

13 Rigid biofoam composites as eco-efficient construction materials

V. Chevali, E. Kandare

13.1 Introduction

13.2 Rigid foams

13.3 Foam processing

283

13.4 Foam morphology and characterisation

285

13.5 Rigid foam composites

13.6 Environmental impact

13.7 Application case studies

297

13.8 Conclusions and future trends

298

References

14 Biopolymers for wood preservation

S. Patachia, C. Croitoru

14.2 Wood preservation mechanisms

14.3 Examples of biopolymer wood preservatives

14.4 Conclusions and future trends

15 Biopolymers for paints and surface coatings

N. Karak

15.1 Introduction

15.2 Concept of biopolymers in paints and coatings 
15.3 Naturally obtained biopolymers used in paints and coatings $\mathbf{3 3 5}$

15.4 Background and importance of biobased polymers 3

15.5 Biobased polymers used for paintings and coatings 341

15.6 Manufacturing of paints and coatings from biobased polymers $\quad \mathbf{3 6 3}$

15.7 Conclusions and future trends $\quad \mathbf{3 6 4}$

References $\quad 365$

16 Bio-based adhesives $\quad 369$

J.-D. Mathias, M. Grédiac, P. Michaud
16.1 Introduction

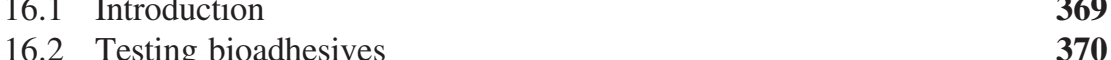

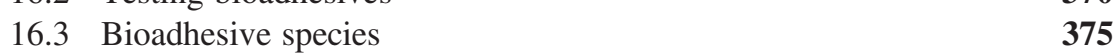

16.4 Discussion and conclusions $\quad 380$

References $\quad 382$

$\begin{array}{lll}17 & \text { Biopolymers as biofilters and biobarriers } & 387\end{array}$

M.A. Ashraf, S. Batool, M. Ahmad, M. Sarfraz, W.S.A.W.M. Noor
17.1 Introduction

$\begin{array}{ll}17.2 \text { Mechanism } & \mathbf{3 9 0}\end{array}$

17.3 Schematic view of contaminant removal by biobarrier 393

17.4 Monitoring the performance of a biofilter/biobarrier 393

17.5 Characterization of biopolymers as a supporter $\mathbf{4 0 2}$

17.6 Removal of contaminants from wastewater $\mathbf{4 1 0}$

$\begin{array}{lll}17.7 & \text { Future trends } & \mathbf{4 1 4}\end{array}$

Acknowledgment $\quad \mathbf{4 1 5}$

References $\quad \mathbf{4 1 5}$

18 Biopolymers for superhydrophobic photocatalytic coatings 421

$\begin{array}{lll}\text { A.Z.M. } & \text { Rus } & \\ \text { 18.1 } & \text { Introduction } & \mathbf{4 2 1} \\ 18.2 & \text { Survey of approaches to biopolymers from renewable resources } & \mathbf{4 2 2} \\ \text { 18.3 } & \text { Development of biopolymer from renewable resources } & \mathbf{4 2 3} \\ \text { 18.4 } & \text { Service life of biopolymers } & \mathbf{4 2 6} \\ \text { 18.5 } & \text { Modification of biopolymers using fillers } & \mathbf{4 2 7} \\ 18.6 & \text { Titanium dioxide as polymer stabilization and photocatalysis } & \\ & \text { agent } & \mathbf{4 2 9} \\ 18.7 & \text { Biopolymers as superhydrophobic photocatalytic coatings } & \mathbf{4 3 0} \\ \text { 18.8 } & \text { Conclusions and future trends } & \mathbf{4 4 4} \\ & \text { References } & \mathbf{4 4 4}\end{array}$

Index 449 
This page intentionally left blank 


\section{List of contributors}

\section{Ahmad Quaid-i-Azam University, Islamabad, Pakistan}

Y. Alvarado-Capó Instituto de Biotecnología de las Plantas, Universidad Central "Marta Abreu" de Las Villas, Santa Clara, Cuba

M.A. Ashraf University of Malaya, Kuala Lumpur, Malaysia; Centre for Research in Biotechnology for Agriculture (CEBAR), University of Malaya, Kuala Lumpur, Malaysia; Universiti Malaysia Sabah, Kota Kinabalu, Sabah, Malaysia

S. Batool University of Malaya, Kuala Lumpur, Malaysia

U.T. Bezerra Federal Institute of Paraíba, João Pessoa-PB, Brazil

G. Bracho Institute "Carlos J. Finlay", Habana, Cuba

A. Callico Institute "Carlos J. Finlay”, Habana, Cuba

P.F. de J. Cano-Barrita Instituto Politécnico Nacional/CIIDIR Unidad Oaxaca, Oaxaca, México

V. Chevali University of Southern Queensland, Toowoomba, QLD, Australia

C. Croitoru Transilvania University of Brasov, Brasov, Romania

H.H.M. Darweesh National Research Center, Cairo, Egypt

Y. Diaz Universidad Central de las Villas, Carretera de Camajuani, Santa Clara, $\mathrm{CP}$, Cuba

M. Grédiac Institut Pascal, Clermont Université, Université Blaise Pascal, Clermont-Ferrand, France; CNRS, UMR, Institut Pascal, Aubière, France

J.O. Guerra de Leon Faculty of Chemistry and Pharmacy, Universidad Central "Marta Abreu" de Las Villas, Santa Clara, Cuba

A. Hereira Faculty of Chemistry and Pharmacy, Universidad Central "Marta Abreu" de Las Villas, Santa Clara, Cuba

V. Ivanov Nanyang Technological University, Singapore

H.M. Jonkers Faculty of Civil Engineering and Geosciences, Materials and Environment Section, Delft University of Technology, Stevinweg, Delft,

The Netherlands 
E. Kandare RMIT University, Melbourne, VIC, Australia

N. Karak Tezpur University, Napaam, Tezpur, Assam, India

A.D. La Rosa University of Catania, Catania, Italy

F.M. León-Martínez Instituto Politécnico Nacional/CIIDIR Unidad Oaxaca, Oaxaca, México

Z. Li University of Arizona, Tucson, AZ, USA

S.H. Lv College of Resource and Environment, Shaanxi University of Science \& Technology, Xi'an, China

F. Martirena Universidad Central de las Villas, Carretera de Camajuani, Santa Clara, CP, Cuba

J.-D. Mathias IRSTEA, Laboratoire d'Ingénierie pour les Systèmes Complexes, Aubière, France

P. Michaud Institut Pascal, Clermont Université, Université Blaise Pascal, Clermont-Ferrand, France; CNRS, UMR, Institut Pascal, Aubière, France

R.M. Mors Faculty of Civil Engineering and Geosciences, Materials and Environment Section, Delft University of Technology, Stevinweg, Delft, The Netherlands

W.S.A.W.M. Noor School of Biosciences and Biotechnology, Faculty of Science and Technology, National University Malaysia (UKM), Bangi, Selangor, Malaysia

F. Pacheco-Torgal University of Minho, Guimarães, Portugal

S. Patachia Transilvania University of Brasov, Brasov, Romania

T.M. Pique Instituto de Tecnología en Polímeros y Nanotecnología UBA/ CONICET (ITPN), Buenos Aires, Argentina; Facultad de Ingeniería, Universidad de Buenos Aires, Buenos Aires, Argentina

Y. Rodriguez-Rodriguez Centro de Bioactivos Químicos (CBQ), Universidad Central "Marta Abreu" de Las Villas, Santa Clara, Cuba

A.Z.M. Rus University Tun Hussein Onn Malaysia (UTHM), Batu Pahat, Johor, Malaysia

M. Sarfraz Institute of Pharmacy, Physiology \& Pharmacology, University of Agriculture, Faisalabad, Pakistan

M.G. Sierra-Beltran Faculty of Civil Engineering and Geosciences, Materials and Environment Section, Delft University of Technology, Stevinweg, Delft, The Netherlands

L. Sorelli Université Laval, Département de Génie Civil, Québec, QC, Canada 
V. Stabnikov Nanyang Technological University, Singapore; National University of Food Technologies, Kiev, Ukraine

A. Vazquez Instituto de Tecnología en Polímeros y Nanotecnología UBA/ CONICET (ITPN), Buenos Aires, Argentina; Facultad de Ingeniería, Universidad de Buenos Aires, Buenos Aires, Argentina

V. Wiktor Faculty of Civil Engineering and Geosciences, Materials and Environment Section, Delft University of Technology, Stevinweg, Delft, The Netherlands

L. Zhang University of Arizona, Tucson, AZ, USA 
This page intentionally left blank 


\section{Woodhead Publishing Series in Civil and Structural Engineering}

1 Finite element techniques in structural mechanics

C. T. F. Ross

2 Finite element programs in structural engineering and continuum mechanics C. T. F. Ross

3 Macro-engineering

F. P. Davidson, E. G. Frankl and C. L. Meador

4 Macro-engineering and the earth

U. W. Kitzinger and E. G. Frankel

5 Strengthening of reinforced concrete structures Edited by L. C. Hollaway and M. Leeming

6 Analysis of engineering structures

B. Bedenik and C. B. Besant

7 Mechanics of solids

C. T. F. Ross

8 Plasticity for engineers

C. R. Calladine

9 Elastic beams and frames

J. D. Renton

10 Introduction to structures

W. R. Spillers

11 Applied elasticity

J. D. Renton

12 Durability of engineering structures

J. Bijen

13 Advanced polymer composites for structural applications in construction Edited by L. C. Hollaway

14 Corrosion in reinforced concrete structures Edited by H. Böhni

15 The deformation and processing of structural materials Edited by Z. X. Guo

16 Inspection and monitoring techniques for bridges and civil structures Edited by $\mathrm{G}$. Fu

17 Advanced civil infrastructure materials Edited by $\mathrm{H}$. Wu

18 Analysis and design of plated structures Volume 1: Stability Edited by E. Shanmugam and C. M. Wang

19 Analysis and design of plated structures Volume 2: Dynamics Edited by E. Shanmugam and C. M. Wang 
20 Multiscale materials modelling Edited by Z. X. Guo

21 Durability of concrete and cement composites Edited by C. L. Page and M. M. Page

22 Durability of composites for civil structural applications Edited by V. M. Karbhari

23 Design and optimization of metal structures

J. Farkas and K. Jarmai

24 Developments in the formulation and reinforcement of concrete Edited by $S$. Mindess

25 Strengthening and rehabilitation of civil infrastructures using fibre-reinforced polymer (FRP) composites

Edited by L. C. Hollaway and J. C. Teng

26 Condition assessment of aged structures

Edited by J. K. Paik and R. M. Melchers

27 Sustainability of construction materials

J. Khatib

28 Structural dynamics of earthquake engineering

S. Rajasekaran

29 Geopolymers: Structures, processing, properties and industrial applications Edited by J. L. Provis and J. S. J. van Deventer

30 Structural health monitoring of civil infrastructure systems Edited by V. M. Karbhari and F. Ansari

31 Architectural glass to resist seismic and extreme climatic events Edited by R. A. Behr

32 Failure, distress and repair of concrete structures Edited by N. Delatte

33 Blast protection of civil infrastructures and vehicles using composites Edited by N. Uddin

34 Non-destructive evaluation of reinforced concrete structures Volume 1: Deterioration processes

Edited by C. Maierhofer, H.-W. Reinhardt and G. Dobmann

35 Non-destructive evaluation of reinforced concrete structures Volume 2: Non-destructive testing methods

Edited by C. Maierhofer, H.-W. Reinhardt and G. Dobmann

36 Service life estimation and extension of civil engineering structures Edited by V. M. Karbhari and L. S. Lee

37 Building decorative materials Edited by $Y$. Li and S. Ren

38 Building materials in civil engineering Edited by $H$. Zhang

39 Polymer modified bitumen Edited by T. McNally

40 Understanding the rheology of concrete Edited by N. Roussel

41 Toxicity of building materials Edited by F. Pacheco-Torgal, S. Jalali and A. Fucic

42 Eco-efficient concrete

Edited by F. Pacheco-Torgal, S. Jalali, J. Labrincha and V. M. John 
43 Nanotechnology in eco-efficient construction

Edited by F. Pacheco-Torgal, M. V. Diamanti, A. Nazari and C. Goran-Granqvist

44 Handbook of seismic risk analysis and management of civil infrastructure systems Edited by F. Tesfamariam and K. Goda

45 Developments in fiber-reinforced polymer (FRP) composites for civil engineering Edited by N. Uddin

46 Advanced fibre-reinforced polymer (FRP) composites for structural applications Edited by J. Bai

47 Handbook of recycled concrete and demolition waste Edited by F. Pacheco-Torgal, V. W. Y. Tam, J. A. Labrincha, Y. Ding and J. de Brito

48 Understanding the tensile properties of concrete Edited by J. Weerheijm

49 Eco-efficient construction and building materials: Life cycle assessment (LCA), eco-labelling and case studies

Edited by F. Pacheco-Torgal, L. F. Cabeza, J. Labrincha and A. de Magalhães

50 Advanced composites in bridge construction and repair Edited by Y. J. Kim

51 Rehabilitation of metallic civil infrastructure using fiber-reinforced polymer (FRP) composites

Edited by V. Karbhari

52 Rehabilitation of pipelines using fiber-reinforced polymer (FRP) composites Edited by V. Karbhari

53 Transport properties of concrete: Measurement and applications P. A. Claisse

54 Handbook of alkali-activated cements, mortars and concretes F. Pacheco-Torgal, J. A. Labrincha, C. Leonelli, A. Palomo and P. Chindaprasirt

55 Eco-efficient masonry bricks and blocks: Design, properties and durability F. Pacheco-Torgal, P. B. Lourenço, J. A. Labrincha, S. Kumar and P. Chindaprasirt

56 Advances in asphalt materials: Road and pavement construction Edited by S.-C. Huang and H. Di Benedetto

57 Acoustic emission (AE) and related non-destructive evaluation (NDE) techniques in the fracture mechanics of concrete: Fundamentals and applications Edited by M. Ohtsu

58 Nonconventional and vernacular construction materials: Characterisation, properties and applications Edited by K. A. Harries and B. Sharma

59 Science and technology of concrete admixtures Edited by P.-C. Aïtcin and R. J. Flatt

60 Textile fibre composites in civil engineering Edited by T. Triantafillou

61 Corrosion of steel in concrete structures Edited by A. Poursaee

62 Innovative developments of advanced multifunctional nanocomposites in civil and structural engineering Edited by K. J. Loh and S. Nagarajaiah

63 Biopolymers and biotech admixtures for eco-efficient construction materials Edited by F. Pacheco-Torgal, V. Ivanov, N. Karak and H. Jonkers 
This page intentionally left blank 


\section{Foreword}

The cliché, never judge a book by its cover, this time seems especially untrue. The very informative title on the familiar cover of Woodhead Publishing Series in Civil and Structural Engineering inspires confidence and interest.

Key words in the title of the book define its goal: Ecoefficient Construction Materials, and simultaneously show the means by which to do that: biopolymers and biotech admixtures. These characteristics could reduce to the common denominator: biotech toward sustainable construction. There is a yardstick of target and the grand scale of engineering ambitions and challenges claimed in this work.

Every material thing comes from something else, and every structure is of construction materials, now mainly from concrete. The construction industry consumes more than $40 \%$ of produced energy and about $50 \%$ mass of materials the building industry also emits $35 \%$ of greenhouse gases. There is no doubt that sustainable development is the fundamental requirement for construction. The notion of sustainable development aspires to the role of a high civilizational ideal. Sustainable development "implies meeting the needs of the present without compromising the ability of future generations to meet their own needs" (Brundtland, 1987). However, a softer definition exists close to the people. Antoine de Saint-Exupery in The Little Prince said: we do not inherit the Earth from our parents; we borrow it from our children. On first impression, this second definition is a leitmotif or underlying theme of the book. Annually over six billion $\mathrm{m}^{3}$ of concrete is produced around the world. It is unrealistic or even impossible to substitute other materials for this concrete. Nevertheless, it is possible or even necessary to modify concrete to use an adequate admixture (see the book title) to make concrete and construction materials ecoefficient, more environmentally friendly. The book provides basic concepts, production aspects, and environmental impact assessments on the use of biopolymers and biotech admixtures for cement mortar and concrete, as well as for soil stability, wood preservation, and coatings in construction applications including bioadhesives, biofilters, and biobarriers. This knowledge is new but well structured, up-to-date, with an enormous number of references. What is more, on each page a reader feels the need for progress in the face of complexity by making sense of every piece of information. The book is rare that is both scholarly and engaging. It is a great work-a magnum opus: 450 pages and 40 contributors. Contrary to that diversity, from a reader's point of view it makes the impression of an integral continuity. We can see here the merit of four experienced editors: V. Ivanov (Singapore), W. Karak (India), and H. Jonkers (The Netherlands) under the guideline of Fernando Pacheco-Torgal (Portugal). It is an excellent example 
of how to make order in informational chaos. Altogether, the contributors could be called the sense makers in the biotech construction material engineering field. The words that were chosen matter to the contributors. They suggest the ideas that the contributors want to bring into the world. The words and sentences can further our plans, fulfill our inspirations. Authors arrange lots of facts, reports, and discoveries in a way that makes it understandable and of value in the engineering field marked by the topical pillars: biotechnology - construction materials - ecology. Readers will feel a familiarity with the architecture of the presented information. What is more, readers feel the right to rely on those information sources and to be professionally active on this area. One of the reasons is a conviction that the authors know their topic and recognize their responsibility, clearly conveyed by the text. Implementing new or even modified construction materials means that we are able to assure durability (often more than 50 years), safety of use, health, and user comfort.

Each chapter shines light on the selected issue: scientific approach for construction biotechnology; biotechnological production; life cycle of biopolymers; biotech admixtures as modifiers for fresh concrete mixture and hardened concrete; microorganismbased bioplasticizers for concrete; fly ash materials; biopolymers for wood preservation; biopolymer coatings, including photocatalytic ones; bioadhesives; biofilters, and biobarriers. Thus, one can outline its edges and depths. The book touches the key problem of how, through experimentation techniques and tests, trials and failures, observations, and theories of construction, researchers have managed to unravel nature's secrets and transform them into technology to achieve progress. Perhaps, the economic aspect is not accented enough.

It is true that biobased admixtures have been used in construction materials for centuries much earlier than the Roman Empire. However, it is also true that contemporary knowledge of this subject is arising almost simultaneously with the appearance of this book. Topicality is one of the extra values of the book.

How we do manage with construction materials in the twenty-first century?-It is one of the basic questions of civilization. Expectations include:

- a new arrangement of the research results,

- a new understanding of the nature of materials,

- a thrust for further development in theory and in application.

The new knowledge will help us to change our activity in our world.

Knowing is not enough, the book also encourages us. It seems that now is the right time. We can lessen our anxiety and follow the book to make progress.

The book appears as the 63rd entry on the list of the Woodhead Publishing Series in Civil and Structural Engineering. Five books published during the last three years have highlighted the significant adjective: Ecoefficient. It is not by accident that it exposes the development trend as a megatrend. The book makes a brilliant trace along this way. We have the essential reading.

Lech Czarnecki

Building Research Institute (ITB)

Warsaw, Poland. 


\title{
Introduction to biopolymers and biotech admixtures for eco-efficient construction materials
}

\author{
F. Pacheco-Torgal \\ University of Minho, Guimarães, Portugal
}

\subsection{Introduction}

For more than half a century the fossil fuel industry has provided the resources for the polymer industry. Independently of the "Peak Oil" never ending discussion (Chapman, 2014), the future scarcity of petroleum resources (Sorrell et al., 2012) is a fact that must be faced sooner or later. Moreover, it does not matter very much that the shale oil euphoria could turn the USA into the world's largest oil producer (Morse, 2014).

Granting the fact, one believes that oil scarcity is not the major issue to be addressed concerning this nonrenewable resource. In the short term, interstate wars and environmental disaster are the major issues. Never before has a commodity triggered so many armed conflicts (Black, 2012). Moreover, since 1973, at least one-quarter of all interstate wars were connected to oil (Verbruggen and van de Graaf, 2013).

States with large oil reserves and unstable political governments tend to instigate conflicts at a rate three and a half times that of comparable states with stable governments and without oil (Colgan, 2013, 2014).

Most importantly, environmental disasters are caused by oil spills like the 1979 Ixtoc 1 off-shore oil rig blowout, which during nine months released 530 million liters of crude oil into the Gulf of Mexico (Jernelov and Linden, 1981; Patton et al., 1980) causing massive damage to maritime ecosystems (Soto et al., 2014). Add to that the 1989 Exxon Valdez oil tanker "small" episode (41 million liters of crude oil) in Alaska that killed hundreds of thousands of seabirds, billions of fish eggs, and many whales and seals (Alford et al., 2014; Malakoff, 2014), and the 2010 British Petroleum (BP)owned Deep Water Horizon oil spill, which released approximately 780 million liters of crude oil into the Gulf of Mexico (Atlas, 2011). These represent the dark side of crude oil production for which no life-cycle analysis can account.

The latter was considered the worst environmental disaster to have occurred in the USA. According to Costanza et al. (2010), this environmental tragedy was responsible for an almost complete shutdown of the $\$ 2.5$ billion per year Louisiana fishing industry and was also responsible for a $\$ 34-\$ 760$ billion loss of ecosystem services in the Mississippi River delta alone. This value exceeds even BP total market value and still 
raises environmental and public health concerns (Ortmann et al., 2012; Wise et al., 2014; Drescher et al., 2014; Gill et al., 2012).

The chronology of other crude oil-related disasters can be seen at Infoplease (2014). In addition, the increase in crude oil transport by oil tankers has led to an increase in collision risk (Morgan et al., 2014).

Because oil exploration is moving into ever-deeper water and into stormier and icier seas, it means increased risks (Jernelov, 2010).

According to Sällh et al. (2015), the share of offshore oil production is expected to increase from $33 \%$ to $48 \%$ by 2030 . This means that the risk of new environmental disasters related to oil production will also increase.

All of the foregoing clearly justifies the search for new and biodegradable polymers based on renewable feedstock.

Recent years have seen a tremendous increase in the number of publication citations on biobased polymers (around $1000 \%$ in the last 10 years). However, the fact is that these materials still constitute only a very small fraction of the polymer industry (Babu et al., 2013).

Biopolymers include polymers from agro-resources (polysaccharides, cellulose, starch, chitin, chitosan, and alginates), from microorganisms by fermentation (polyhydroxyalkanoates, such as polyhydroxybutyrate) and from biotechnology via conventional synthesis (polylactides (PLA), polybutadiene succinate, biopolyethylene (PE), polytrimethylene terephthalate, poly-p-phenylene) (Avérous and Pollet, 2012). Although some are biodegradable, that is not always the case, like, for instance, PE.

It is clear that the farming practices used to grow biobased feedstock including the fuel required for plowing, harvesting, manufacture, and transport, and the use of herbicides and pesticides, can also have environmental impacts as high as those of petrochemical-based polymers (Yates and Barlow, 2013). However, biopolymers are not associated with armed conflicts, nor are they responsible for large environmental disasters that so often occur in crude oil extraction and transportation. Besides, the reuse of agricultural and biomass waste will contribute to the environmental advantages of biopolymers over traditional petroleum-based polymers (Gopalakrishnan et al., 2012, 2013; Hottle et al., 2013).

\subsection{Biopolymers and biotech admixtures for eco-efficient construction materials}

Bio-based admixtures have been used in construction materials for centuries. The use of air lime mortars with the addition of vegetable fat goes back to Vitruvius of the Roman Empire (Albert, 1995).

The Romans also had recognized the role of bio-admixtures to improve their building materials; for example, dried blood was used as an air-entraining agent, whereas biopolymers such as proteins served as set retarders for gypsum (Plank, 2003).

The Chinese already have used egg white, fish oil, and blood-based mortars during the construction of the Great Wall due to their imperviousness (Yang, 2012). 
In 1507, mortars based on lime mixed with small amounts of vegetable oil added during the slaking process were used in the construction of the Portuguese fortress, "Nossa Senhora da Conceição," located on Gerum Island, Ormuz, Persian Gulf (Pacheco-Torgal and Jalali, 2011). More than 300 years after the fortress construction, A. W. Stiffe, a Lieutenant of the British Navy, visited the interior of the fortress and made a description of its conservation status for Geographical Magazine. He stated that "The mortar used was excellent, and much more durable than the stones" (Rowland, 2006).

The twentieth century became the age of admixtures, the history of which started in the 1920s with the introduction of lignosulfonate, a biopolymer, for Ordinary Portland Cement (OPC) concrete plasticization, the first functional polymer used in construction on a large scale (Plank, 2004).

OPC concrete, a typical civil engineering construction material, is the most used material on Planet Earth. Its production reaches 10,000 million tons/year and in the next 40 years will increase around 100\% (Pacheco-Torgal et al., 2013b).

Currently, around $15 \%$ of the total OPC concrete production contains chemical admixtures to modify their properties, either in fresh or hardened state. Concrete super plasticizers based on synthetic polymers include melamine, naphthalene condensates, or polycarboxylate copolymers to improve their workability, strength, and durability. Examples of biopolymers used in concrete include lignosulfonate, starch, chitosan, pine root extract, protein hydrolysates, or even vegetable oils. Bioresins based on polyfurfuryl alcohol and produced from agricultural wastes have recently been used with interesting results in engineering structures (Gkaidatzis, 2014).

Biotech admixtures made in fermentation processes by employing bacteria (Pei et al., 2015) or fungi seem to have received an increased attention, because their biosynthesis rate is about two to four times higher than that of plant-based biopolymer (Ivanov et al., 2014). These admixtures include sodium gluconate, xanthan gum, curdlan, or gellan gum. Nevertheless, investigations on the use of biopolymers in OPC are still residual. Of the 8159 Scopus-referenced journal papers published since 2000 and related to OPC, fewer than $1 \%$ are related to the use of biopolymers.

The construction industry has become a major field of use for biopolymers. In 2000, an estimated \$2 billion in sales was made at the manufacturer's level, and this growth is expected to continue. Although OPC and dry-mix mortars consume the majority of biopolymers, a great diversity of bio-admixtures with well over 500 different products is now used by other building materials industries (Plank, 2004).

In the next few years, the construction industry will keep on growing at a fast pace just to accommodate urban population increase that will almost double, increasing from approximately 3.4 billion in 2009 to 6.4 billion in 2050 (World Health Organization (WHO, 2014)). Recent estimates on urban expansion suggest that until 2030 urban land cover will increase by 1.2 million $\mathrm{km}^{2}$ (Seto et al., 2012). Therefore, demand for biopolymer-based construction materials will also increase (Ashby, 2015).

The nanotech advancements that have recently occurred will allow for the development of new and improved biopolymer-based materials. Investigations on cellulose nanocrystals (cellulose elements having at least one dimension in the $1-100 \mathrm{~nm}$ range) constitute an important and recent nanotechnology field that will enable the 
development of eco-efficient high-performance materials (Charreau et al., 2013; Chirayil et al., 2014).

The potential of nanocellulose materials can be perceived from the increase in the number of papers published involving keywords like nanocellulose, cellulose nanocrystals, or cellulose nanocomposites (Figure 1.1).

According to Mariano et al. (2014), the number of papers in this area is expected to increase by a further $500 \%$ by at least 2017 , leading to an increase in perspective production in the range of $1000 \%$ in the following two years. However, the transition from advanced research to practical applications for the built environment is likely to take several years.

Cellulose, being the most abundant organic polymer on Earth and representing about 1.5 trillion tons of the total annual biomass production (Kim et al., 2015), is renewable, biodegradable, and carbon neutral. It has the potential to be processed at industrial-scale quantities and at low cost compared to other materials. The cellulose nanocrystals represent a potential green alternative to carbon nanotubes for reinforcing materials such as polymers and concrete.

Dri et al. (2013) used models based on the atomic structure of cellulose showing that these crystals have a stiffness of $206 \mathrm{GPa}$, which is comparable to that of steel.

Other authors (Dufresne, 2013) showed that the specific Young's modulus of cellulose nanocrystals, which is the ratio between the Young's modulus and the density of cellulose crystal, is around $85 \mathrm{Jg}^{-1}$, in comparison to around $25 \mathrm{Jg}^{-1}$ for steel.

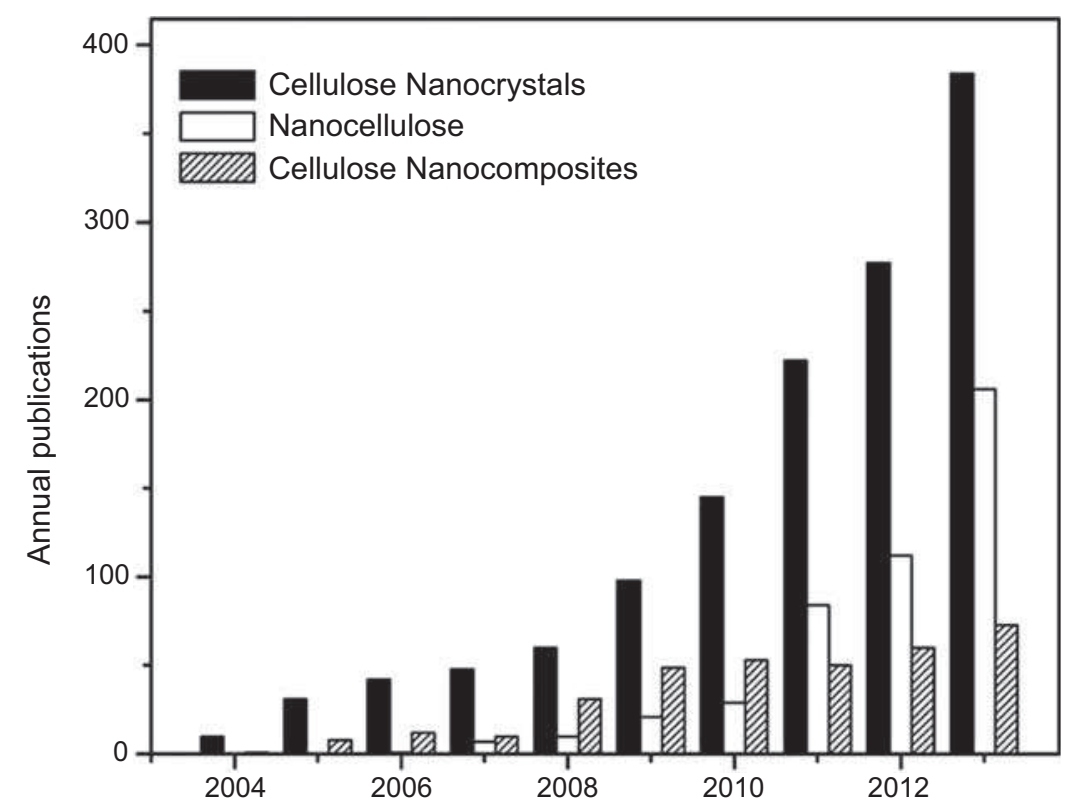

Figure 1.1 Number of publications related with nanocellulose terms during the last decade. Data from main scientific databases. Reprinted from Mariano et al. (2014). Copyright ( 2012 , with permission from Elsevier. 
So far, some uses of nanocrystalline cellulose to improve the modulus of elasticity of cement boards have already been patented (Thomson et al., 2010). The cement industry has a potential nanocellulose market of over 4 million metric tons (Cowie et al., 2014).

Because biopolymers like chitosan, PLA, or starch have poor mechanical performance when compared to synthetic polymers, the use of cellulose nanofibers as reinforcing nanomaterials can help turn those biopolymers into biocomposites with high mechanical strength (Kim et al., 2015).

Cellulose aerogel is another promising application concerning the development of high-performance thermal-insulator building materials (Gavillon and Budtova, 2008; Chen et al., 2014; Nguyen et al., 2014).

Promising results on high-performance nanocellulose-based thermal insulators with fire retardant properties were recently disclosed (Wicklein et al., 2015).

High-performance thermal insulators are materials with a thermal conductivity lower than $0.020 \mathrm{~W} / \mathrm{m} \mathrm{K}$, whereas current (petroleum-based) insulator materials like expanded polystyrene (EPS) and extruded polystyrene (XPS) have values around $0.03-0.06 \mathrm{~W} / \mathrm{m} \mathrm{K}$. This is a very important application because the use of thermal insulation materials constitutes the most effective way of reducing heat losses in buildings, thus increasing their energy efficiency. It is worth remembering that the building sector is the largest energy user, responsible for about $40 \%$ of the European Union (EU)'s total final energy consumption (Lechtenbohmer and Schuring, 2011). According to the Energy Road Map 2050 (European Commission, 2011), higher energy efficiency in new and existing buildings is key for the transformation of the EU's energy system. The European Energy Performance of Buildings Directive (EPBD) 2002/91/ EC has been recast in the form of Directive 2010/31/EU by the European Parliament on May 19, 2010. One of the new aspects of the EPBD is the introduction of the concept of nearly zero-energy building (Pacheco-Torgal et al., 2013a). Building energy efficiency merits special funding under the HORIZON 2020 EU framework program (Pacheco-Torgal, 2014). In addition, the European market for building energy products and services will reach 80 billion euro by 2023 (Navigant Research, 2014).

Besides, because aerogels are nonflammable, they do not release toxic fumes upon burning as do current insulation materials like EPS or XPS (Pacheco-Torgal et al., 2012), which constitutes an extra advantage.

Some books have already been published concerning biopolymers and biotech admixtures. However, some have absolutely nothing on construction materials, whereas others have just one or two chapters on biobased admixtures for cement and plasters. To the best of my knowledge, none has ever been published that provides a wide view on the subject as does this one. Assembled by a team of leading international expert contributors, this book constitutes an innovative approach on biopolymers and biotech admixtures for eco-efficient construction materials.

\subsection{Outline of the book}

This book provides an updated state-of-the-art review on the eco-efficiency of biopolymers and biotech admixtures for construction materials. It includes basic concepts, 
production aspects, environmental impact assessment, the use of biopolymers and biotech admixtures for cement, mortar, and concrete, and covers other construction applications like biobased paintings and coatings, bioadhesives, biofilters, and biobarriers.

The first part of the book encompasses the production of biopolymers for eco-efficient construction materials (Chapters 2-4).

In Chapter 2, basic concepts on biopolymers and biotech admixtures for ecoefficient construction materials are introduced. The different types of biopolymers are reviewed. The case of polysaccharides and their applications in civil engineering are described. Microbial-based bioplastics are covered. Biocements and biogrouts are also covered.

Chapter 3 addresses production aspects of biopolymers and biotech admixtures for eco-efficient construction materials. The following approaches are reviewed: (1) solid or liquid organic wastes, such as food processing, municipal, or mining wastes, used as base materials; (2) aseptic cultivation of microorganisms without sterilization of medium and equipment; and (3) reducing or eliminating the stage of product concentration and purification.

Chapter 4 discusses the life-cycle analysis of biopolymers. The chapter first introduces the concept of biopolymers and the main advantages of shifting from traditional petroleum-derived polymers to biomass-derived polymers. Case studies are reported on the life-cycle assessment of biopolymers used in several sectors with a major focus on the building sector.

Biopolymers and biotech admixtures in cement and mortars are the subject of Part II (Chapters 5-9).

Chapter 5 is concerned with biotech admixtures for enhancing Portland cement hydration. The influence of different polymers including cellulose ethers, hydroxypropylmethyl cellulose, hydroxyethylmethyl cellulose, hydroxyethyl cellulose, chitosan, Diutan gum, gellan gum, xanthan, lignosulfonates, starch, and microcellulose are reviewed.

Chapter 6 covers the utilization of pulp black-liquor waste, a by-product from the papermaking industry as a cement admixture. Its influence on the physical and mechanical properties of cement pastes is analyzed. Infrared spectra and microstructure analysis are included. The optimum pulp black-liquor waste percentage is determined.

Chapter 7 analyzes the use of biopolymer chitosan-based high-performance superplasticizer. The preparation principles and major influence factors as well as the relationship of structure and properties are included. The application properties of the chitosan superplasticizer, such as fluidity, adsorption behavior, and impact on mechanical strength and microstructure of concrete, are studied.

Chapter 8 addresses the case of a new bioproduct produced through fermentation of a mixed culture of microorganisms as a plasticizer in concrete. The bio-admixture has a broad impact on cement and concrete properties probably caused by the various compounds present, and thus the various mechanisms of influence act in a synergetic way. Applications such as plasticizers and viscosity-controlling agents in concrete are discussed. Practical examples of self-compacting and normal concrete are also discussed.

Chapter 9 addresses the performance of fly ash-based geopolymer with kappacarrageenan biopolymer (KC), a seaweed extract. Mechanical tests are conducted to 
study the improvement of strength and prepeak toughness, and scanning electron microscopy and Fourier transform infrared are employed to study the microstructural and chemical evolution when different amounts of $\mathrm{KC}$ are incorporated in the fly ash-based geopolymer paste specimens.

Part III (Chapters 10-13) deals with biopolymers and biotech admixtures in concrete.

Chapter 10 reviews biopolymers with superplasticizer properties for both fresh and hardened states of concrete. It includes aspects on concrete microstructure and concrete modeling.

Chapter 11 discusses biopolymers with viscosity-enhancing properties for concrete. The chemical structure, modes of action, rheological properties, and impact on cement hydration of commonly used viscosity-enhancing admixtures derived from biological sources are analyzed.

Chapter 12 looks at biotech solutions for concrete repair with enhanced durability. Two different specific systems for biotechnological repair of concrete structures are discussed. The first one covers liquid biobased repair systems for durable repair of cracked and porous concrete surfaces, and the second one addresses biobased mortar systems for repair of larger defects of concrete structures.

Finally, Part IV concerns other biopolymer applications (Chapters 13-18).

Chapter 13 is concerned with biofoam composites. Suggestions for damage prevention including utilization of additives and reinforcements in obtaining multifunctionalities are reported. Common design methodologies used in construction materials are presented.

Chapter 14 addresses the use of biopolymers for wood preservation. It reviews wood-degradative factors, their mechanism of action, and the method for diminishing them.

Chapter 15 is concerned with biopolymers for paintings and coatings. It covers the case of biobased polymers like polyester, poly(ester amide), epoxy, and polyurethane. It presents a typical preparative method for industrial painting based on biopolyester.

Chapter 16 reviews biobased adhesives covering the different existing families of adhesives.

Chapter 17 reviews biopolymers as biofilters and biobarriers. Mechanisms of biofiltration are reviewed. The performance of biopolymer-based barriers is included. The use of biobarriers for the removal of inorganic contaminants from wastewater is also covered.

Chapter 18 closes Part IV with a case study on biopolymers for superhydrophobic photocatalysis coatings, which prevent algae or moss deposits on façade or building roofs.

\section{References}

Ashby, F., 2015. Materials and Sustainable Development, first ed. Butterworth-Heinemann, Elsevier, Oxford, UK.

Albert, L.B., 1995. Ten Books on Architecture. Oxford University Press, London. 
Alford, J., Peterson, M., Green, C., 2014. Impacts of Oil Spill Disasters on Marine Habitats and Fisheries in North America. In: CRC Marine Biology Series. CRC Press, 340 pp.

Atlas, R., 2011. Oil biodegradation and bioremediation: a tale of the two worst spills in U.S. history. Environmental Science and Technology 45, 6709-6767.

Babu, R., O'Connor, K., Seeram, R., 2013. Current progress on bio-based polymers and their future trends. Progress in Biomaterials 2 (8).

Black, B., 2012. Crude Reality: Petroleum in World History. Rowman \& Littlefield Publishers, 288 pp.

Chapman, I., 2014. The end of peak oil? Why this topic is still relevant despite recent denials. Energy Policy 64, 93-101.

Charreau, H., Foresti, M., Vazquez, A., 2013. Nanocellulose patents trends: a comprehensive review on patents on cellulose nanocrystals, microfibrillated and bacterial cellulose. Recent Patents on Nanotechnology 7, 56-80.

Chen, W., Li, Q., Wang, Y., Yi, X., Zheng, J., Yu, H., Liu, Y., Li, J., 2014. Comparative study of aerogels obtained from differently prepared nanocellulose fibres. ChemSusChem 7 , $154-161$.

Chirayil, C., Mathew, L., Thomas, S., 2014. Review of recent research in nanocellulose preparation from different lignocellulosic fibers. Reviews on Advanced Materials Science 37, $20-28$.

Colgan, J., 2014. Oil, domestic politics, and international conflict. Energy Research \& Social Science 1, 198-205.

Colgan, J., 2013. Fueling the Fire: The Pathways from Oil to War. International Security MIT Press.

Costanza, R., Batker, D., Day Jr., J.W., Feagin, R.A., Martinez, M., Roman, J., 2010. The perfect spill: solutions for averting the next deepwater horizon. Solutions: For A Sustainable \& Desirable Future 1 (5), 17-20.

Cowie, J., Bilek, E., Wegner, T., Shatkin, J., 2014. Market projections of cellulose nanomaterialenabled products - part 2: volume estimates. Tappi Journal 13, 57-69.

Drescher, C., Schulenberg, S., Smith, E., Veronica, C., March 2014. The Deepwater horizon oil spill and the Mississippi Gulf Coast: mental health in the context of a technological disaster. American Journal of Orthopsychiatry 84 (2), 142-151.

Dri, F., Hector, L., Moon, R., Zavattieri, P., 2013. Anisotropy of the elastic properties of crystalline cellulose $\mathrm{I} \beta$ from first principles density functional theory with Van der Waals interactions. Cellulose 20, 2703-2718.

Dufresne, A., 2013. Nanocellulose: a new ageless bionanomaterial. Materials Today 16, $220-227$.

European Commission, 2011. Energy Roadmap 2050. COM(2011) 885/.EC, Brussels.

Gavillon, R., Budtova, T., 2008. Aerocellulose: new highly porous cellulose prepared from cellulose- $\mathrm{NaOH}$ aqueous solution. Biomacromolecules 9, 269-277.

Gkaidatzis, R., 2014. Bio-based FRP Structures: A Pedestrian Bridge in Schiphol Logistics Park (Master thesis). TU Delft.

Gill, D., Ritchie, L., Picou, J., Langhinrichsen-Rohling, M., Shenesey, J., January 2012. The Exxon Valdez and BP oil spills: a comparison of psychosocial impacts. Natural Hazards, American Behavioral Scientist 56 (1), 3-23.

Gopalakrishnan, H., Ceylan, H., Kim, S., 2013. Renewable biomass-derived lignin in transportation infrastructure strengthening applications. International Journal of Sustainable Engineering 6, 316-325.

Gopalakrishnan, H., van Leeuwen, J., Brown, R., 2012. Sustainable Bioenergy and Bioproducts. Value added Engineering and Applications. Springer. 
Hottle, T., Bilec, M., Landis, A., 2013. Sustainability assessments of bio-based polymers. Polymer Degradation and Stability 98 (2013), 1898-1907.

Infoplease, 2014. Oil spills and disasters. http://www.infoplease.com/ipa/A0001451.html. Accessed December 2014

Ivanov, V., Chu, J., Stabnikov, V., 2014. Basics of construction microbial biotechnology. In: Pacheco-Torgal, F., Labrincha, J., Diamanti, M., Yu, C.-P., Lee, H. (Eds.), Biotechnologies and Biomimetics for Civil Engineering. Springer Verlag, London.

Jernelov, A., 2010. The threats from oil spills: now, then and in the future. Ambio 39, 353-366.

Jernelov, A., Linden, O., 1981. Ixtoc I: a case study of the world's largest oil spill. Ambio 10 (6), 299-306.

Kim, J.-H., Shim, B., Kim, H., Lee, Y.-J., Min, S.-K., Jang, D., Abas, B., Kim, J., 2015. Review of nanocellulose for sustainable future materials. International Journal of Precision Engineering and Manufacturing Green Technology 2 (2), 197-213.

Lechtenbohmer, S., Schuring, A., 2011. The potential for large-scale savings from insulating residential buildings in the EU. Energy Efficiency 4, 257-270.

Avérous, L., Pollet, E., 2012. Biodegradable polymers. In: Environmental Silicate Nanobiocomposites. Green Energy and Technology. Springer, Hiedelberg, pp. 13-39.

Malakoff, D., 2014. 25 years after the Exxon Valdez, where are the herring? Science 28 (6178), 1416.

Mariano, M., El Kissi, N., Dufresne, A., 2014. Cellulose nanocrystals and related nanocomposites: review of some properties and challenges. Journal of Polymer Science 52 (12), 791-806.

Morgan, A., Shaw-Brown, K., Bellingham, I., Lewis, A., Pearce, M., Pendoley, K., 2014. Global oil spills and oiled wildlife response effort: implications for oil spill contingency planning. In: International Oil Spill Conference Proceedings: May 2014, vol. 2014 (1), pp. $1524-1544$.

Morse, E., 2014. Welcome to the revolution. Why shale is the next shale. Foreign Affair 93 (3).

Navigant Research, 2014. Energy Efficient Buildings: Europe. http://www.navigantresearch. $\mathrm{com} /$ research/energy-efficient-buildings-europe.

Nguyen, T., Feng, J., Ng, S., Wong, J., Tan, V., Duong, H., 2014. Advanced thermal insulation and absorption properties of recycled cellulose aerogels. Colloids and Surfaces A: Physicochemical and Engineering Aspects 445, 128-134.

Ortmann, A.C., Anders, J., Shelton, N., Gong, L., Moss, A.G., et al., 2012. Dispersed oil disrupts microbial pathways in pelagic food webs. PLoS One 7 (7), e42548.

Pacheco-Torgal, F., 2014. Eco-efficient construction and building materials research under the EU framework programme horizon 2020. Construction and Building Materials 51, 151-162.

Pacheco-Torgal, F., Labrincha, J.A., Jalali, S., John, V.M., 2013a. Eco-efficient Concrete. Woodhead Publishing Limited Abington Hall, Cambridge, UK.

Pacheco-Torgal, F., Cabeza, L., Mistretta, M., Kaklauskas, A., Granqvist, C.G., 2013b. Nearly Zero Energy Building Refurbishment. A Multidisciplinary Approach. Springer Verlag, London.

Pacheco-Torgal, F., Fucic, A., Jalali, S., 2012. Toxicity of Building Materials. Woodhead Publishing Limited Abington Hall, Cambridge, UK.

Pacheco-Torgal, F., Jalali, S., 2011. Eco-efficient Construction and Building Materials. Springer Verlag, London, UK.

Pei, R., Liu, J., Wang, S., 2015. Use of bacteria cell walls as a viscosity-modifying admixture of concrete. Cement and Concrete Composites 55, 186-195.

Plank, J., 2004. Application of biopolymers and other biotechnological products in building material. Applied Microbiology and Biotechnology 66, 1-9. 
Plank, J., 2003. Applications of biopolymers in construction engineering. Biopolymers Online $29-39$.

Patton, J., Rigler, M., Boehm, P., Fiest, D., 1980. Ixtoc 1 oil spill: flaking of surface mousse in the Gulf of Mexico. Nature 290, 235-238.

Rowland, P.B., 2006. Essays on Hormuz. http://www.dataxinfo.com/hormuz/essays/3.6.pdf.

Sällh, D., Wachtmeister, H., Tang, X., Höök, M., 2015. Offshore oil: Investigating production parameters of fields of varying size, location and water depth. Fuel 139, 430-440.

Seto, K.C., Buneralp, B., Hutyra, L.R., 2012. Global forecasts of urban expansion to 2030 and impacts on biodiversity and carbon pools. PNAS 17-21.

Sorrell, S., Speirs, J., Bentley, R., Miller, R., Thompson, E., 2012. Shaping the global oil peak: a review of the evidence on field sizes, reserves growth, decline rates and depletion rates. Energy 37, 709-724.

Soto, L., Botello, A., Licea-Duran, S., Lizarra-Partida, M., Yanez-Arancibia, A., 2014. The environmental legacy of the Ixtoc 1 oil spill in Campeche Sound, southwestern Gulf of Mexico. Frontiers in Marine Science 1, 57. http://dx.doi.org/10.3389/fmars.2014.00057.

Thomson, S.L., O’Callaghan, D.J., Westland, J.A., Su, B., 2010. Method of Making a Fiber Cement Board with Improved Properties and the Product US20100162926A1. http://www. google.com/patents/US20100162926.

Verbruggen, A., van de Graaf, V., 2013. Peak oil supply or oil not for sale? Futures 53, 74-85.

WHO, 2014. Urban population growth. Global health observatory.

Wicklein, B., Kocjan, A., Salazar-Alvarez, G., Carosio, F., Camino, G., Antonietti, M., Bergstrom, L., 2015. Thermally insulating and fire retardant lightweight anisotropic foams based on nanocellulose and graphene oxide. Nature Nanotechnology 10, 277-283.

Wise, J.P., Wise, J.T.F., Wise, C.F., Wise, S.S., Gianios, C., Xie, H., Thompson, W., Perkins, C., Falank, C., 2014. Concentrations of the genotoxic metals, chromium and nickel, in whales, tar balls, oil slicks, and released oil from the Gulf of Mexico in the immediate aftermath of the deepwater horizon oil crisis: is genotoxic metal exposure part of the Deepwater Horizon legacy? Environmental Science and Technology 48 (5), 2997-3006.

Yang, J., 2012. Intelligent Systems Analyzing Sections of the Great Wall of China for Ming and Pre-Ming Dynasty Construction (Electronic thesis or dissertation). Retrieved from: https:// etd.ohiolink.edu/.

Yates, M., Barlow, C., 2013. Life cycle assessments of biodegradable, commercial biopolymers-A critical review. Resources, Conservation and Recycling 78, 54-66. 